\title{
DNA Fragments of Altered Electrophoretic Mobility in Leukemia Samples Can Arise from Double-Strand DNA Breaks at Nuclease Hypersensitive Sites of Active Genes
}

\author{
Susan Miesfeldt, Suil Kim, Curtis A. Hanson, Paul R. Bohjanen, \\ Jeffrey M. Leiden, William M. Crist, Andrew J. Carroll, \\ and Craig B. Thompson
}

\begin{abstract}
Chromosome translocations that disrupt or alter gene function have been implicated in the pathogenesis of a variety of malignancies. Therefore, identification of a translocation breakpoint has become a more important means by which to identify genes involved in cellular transformation. A common site of translocation in myeloid and lymphoid malignancies involves 11q23. One human protooncogene, ETS1, has been localized to this chromosomal segment, and several tumors with 11q23 translocations have been shown to have altered ETS1 DNA migration after restriction enzyme digestion. Two laboratories, however, have recently localized the 11q23 breakpoint region to a small region of DNA telomeric of the CD3 loci, a region at considerable distance from the ETS1 gene locus. Therefore, it is difficult to reconcile the studies that suggest altered migration of fragments associated with ETS1 and lack of a localization of the breakpoint to a region near the ETS1 gene. Recently, in our studies to characterize the promoter/enhancer region of the ETS1 protooncogene, we had the opportunity to analyze DNA from 18 patients with acute leukemia involving chromosome 11q23 aberrations. We were unable to demonstrate rearrangement of the ETS1 gene in this group, thus confirming that the 11q23 breakpoint does not involve ETS1 protooncogene. In one patient, however, a DNA break in the region of the ETS1 promoter was detected reproducibly. This DNA break was mapped to the major DNasel hypersensitive site in the ETS1 promoter. Mapping from both sides of the break demonstrated that the break must have occurred during processing of the leukemic cells for DNA analysis. Therefore, artifactual DNA breaks can occur at nuclease-hypersensitive sites of active genes. These data suggest that previous reports of chromosomal translocations involving the ETS1 protooncogene may have resulted from DNA breaks at nuclease hypersensitive sites. This mechanism may account for sporadic case reports of altered restriction enzyme fragment migration involving genes that are not ultimately shown to be associated with the chromosome translocation being examined.
\end{abstract}

\section{INTRODUCTION}

The human protooncogene ETS1 was identified by homology to the v-ets sequence of the E26 avian retrovirus [1]. In

From the Howard Hughes Medical Institute (S. M., J. M. L., C. B. T.), Department of Internal Medicine (J. M. L., C. B. T.), Molecular and Cell Biology Program (C. A. H.), Department of Pathology (J. M. L., C. B. T.), Department of Microbiology and Immunology, University of Michigan Medical Center, Ann Arbor, Michigan, Department of Hematology/Oncology, St. Jude Children's Research Hospital, Memphis, Tennesse (W. M. C.), Department of Pediatrics, University of Tennessee, Memphis College of Medicine; Laboratory of Medical Genetics, University of Alabama at Birmingham, Birmingham, Alabama, (A. J. C.), and Pediatric Oncology Group (POG), St. Louis, Missouri (W. M. C., A. J. C.).

Address reprint requests to: Craig B. Thompson, M.D., Howard Hughes Medical Institute, 5841 S. Maryland Ave, MC 1028, AMB N-101, Chicago, IL 60637.

Received September 18, 1992; accepted February 25, 1993. chicken, the E26 retrovirus is responsible for a mixed erythroid and myeloid leukemia [2,3]. The cellular homologue of v-ets is selectively expressed by quiescent $T$ and $B$ lymphocytes $[4,5]$. We and other investigators have shown that ETS1 encodes a sequence-specific nuclear transcription factor [6-8]. The high-level ETS1 expression observed in quiescent peripheral blood T cells decreases to undetectable levels when T-cell proliferation is induced by T-cell receptormediated stimulation [9]. Similar events occur upon B-cell activation [10]. These data have raised the possibility that ETS1 may act to maintain lymphoid cells in the quiescent state and thus is a potential antioncogene.

The human ETS1 protooncogene has received considerable attention because it is located on chromosome 11q23 [11], a breakpoint commonly associated with acute leukemia. The chromosomal localization of ETS1 has led several investigators to speculate that malignant transformation associated with 11q23 aberrations may be due to a disruption or altera- 
tion of the ETS1 gene [12-16]. Pulse field analysis of one tumor line demonstrated that the break of 11q23 mapped between the $\mathrm{CD} 3$ and ETS1 genes [17]. In addition, in two studies, isolated cases of altered ETS1 migration after restriction enzyme digestion associated with 11q23 translocations was reported [12, 13]. Other studies, however, have failed to document breakpoints in the v-ets homologous domain of ETS1 [14-16]. As part of our studies to characterize the ETS1 promoter, we examined the ETS1 promoter region for translocation in 18 cases of malignancy associated with 11q23 translocations. Consistent with recently published results demonstrating that $11 \mathrm{q} 23$ translocations occur at a considerable distance from the ETS1 gene [18, 19], we failed to document any chromosome translocations associated with 11q23. However, we did identify a patient whose leukemic cell DNA consistently showed an altered ETS1 restriction enzyme fragment pattern using multiple restriction enzymes. Analysis showed that these alterations were within the promoter region of ETS1. We demonstrated that this altered restriction enzyme fragment resulted from a double strand break that mapped to the major DNaseI-hypersensitive site associated with the ETS1 promoter. Thus, our study demonstrates that altered restriction enzyme fragment migration can result from artifactual DNA breaks occurring at major DNasel-hypersensitive sites in leukemic cells. In light of this, our work provides an important cautionary tale for workers investigating potential sites of chromosomal translocations.

\section{MATERIALS AND METHODS}

\section{Patient Material}

Bone marrow (BM) samples from patients with acute leukemia were screened for cytogenetic abnormalities as part of a routine diagnostic workup. Eighteen patients were selected based on chromosome aberrations involving 11q23 and extensive BM involvement with leukemic cells, and three patients with apparent deletions of chromosome 11 that included $11 \mathrm{q} 23$ were selected. Table 1 summarizes the cytogenetic abnormalities of these patients. Fourteen samples were supplied by the Pediatric Oncology Group, St. Louis, MO, and seven were from The University of Michigan Medical Center, Ann Arbor, Michigan. Genomic DNA was isolated, as previously described [20], from purified leukemic cells as well as from peripheral blood (PB) cells from seven normal subjects.

\section{Genomic Southern Blot Analysis}

Genomic DNA ( $5 \mu \mathrm{g}$ ) from BM of patients with acute leukemia or white blood cells (WBC) from normal controls was digested with various restriction enzymes according to conditions suggested by the manufacturer. DNA fragments were fractionated according to size by electrophoresis on $0.7 \%$ or $0.9 \%$ agarose gels and were transferred to nitrocellulose. Membranes were baked at $80^{\circ} \mathrm{C}$ for 2 hours under vacuum and then prehybridized at $42^{\circ} \mathrm{C}$ in a solution containing $50 \%$ formamide, $5 \times$ SSC, $1 \times$ Denhardt's solution, $25 \mathrm{mM}$ sodium phosphate (pH 6.5), and $250 \mu \mathrm{g} / \mathrm{ml}$ Torula RNA for 3-4 hours. Hybridizations were performed for 18 to 24 hours under similar conditions except for addition of $10 \%$ dextran sulfate and $1 \times 10^{6} \mathrm{cpm} / \mathrm{ml}$ of the specific DNA probe $\left(2 \times 10^{5}-10^{6}\right.$ $\mathrm{cpm} / \mathrm{ng}$ probe). The DNA probe consisted of a 442 base pair (bp) EcoRI/Xbal fragment from the 5' end of a 1,900-bp ETS1 cDNA [7]. This probe contained 58 bp of $5^{\prime}$ untranslated region and $384 \mathrm{bp}$ of ETS1 coding sequence, ending at an internal XbaI site (Fig. 1). DNA probes were labeled by nick translation. After hybridization, membranes were washed for 10 minutes at room temperature in $2 \times$ SSC, $0.1 \%$ SSC and then for 1 hour at $55^{\circ} \mathrm{C}$ in $0.1 \times$ SSC, $0.1 \%$ SSC. Membranes were then air-dried briefly and exposed to XAR film for varying times at $-70^{\circ} \mathrm{C}$ with intensifying screens.

\section{Analysis of DNaseI-Hypersensitive Sites}

Nuclei were isolated from human peripheral $\mathrm{T}$ cells after cell lysis in RSB buffer ( $10 \mathrm{mM}$ Tris [pH 7.4], $10 \mathrm{mM} \mathrm{NaCl}, 5 \mathrm{mM}$ $\mathrm{MgCl}_{2}$ ) containing $0.5 \% \mathrm{NP}-40$. The nuclei were resuspended to a concentration of approximately $10^{\mathrm{g}} / \mathrm{ml}$, and equal aliquots were exposed to increasing concentrations of DNaseI for 15 minutes. DNaseI digestions were stopped by adding equal volumes of a solution containing $1 \%$ SDS, $600 \mathrm{mM}$ $\mathrm{NaCl}, 20 \mathrm{mM}$ Tris ( $\mathrm{pH}$ 7.4), and $5 \mathrm{mM}$ EDTA. DNA was then isolated and analyzed as outlined above.

\section{Isolation and Characterization of Genomic Clones}

Approximately $1 \times 10^{6}$ recombinant phage from a Sau3A partial digest of normal human PBL DNA cloned into $\lambda$ Fix (Stratagene, San Diego, CA) (a gift from Dr. J. Lowe, University of Michigan, Ann Arbor, MI) were screened with the ${ }^{32}$ P-labeled ETS1-specific DNA probe described above. Positively hybridizing clones were purified to homogeneity by restriction endonuclease and partial DNA sequence analysis.

\section{RESULTS}

11q23 is a common breakpoint observed in acute leukemia. Because the protooncogene ETS1 had been localized to 11q23, investigators have hypothesized that ETS1 rearrangement plays a role in the leukemic process [12-16]. Although this hypothesis was tested previously by investigators who used DNA probes homologous to the $3^{\prime}$ region of human ETS1 to examine Southern blots of normal and leukemic DNA, we used a novel ETS1 probe from the 5' region of the human cDNA to seek rearrangements in the promoter/enhancer region of ETS1.

Southern blot analyses were performed using DNA samples from seven normal control subjects and 21 leukemic patients with chromosome 11q23 aberrations. These blots were hybridized with the 442-bp XbaI fragment isolated from the $5^{\prime}$ terminus of the human ETS1 cDNA (Fig. 1). If rearrangement of the ETS1 gene occurred in these patients we would expect to see novel bands in the digests of leukemic DNA as compared with control DNA. Southern blots of control DNAs digested with BamHI, EcoRI, HindIII and KpnI were prepared. After hybridization with the 5' ETS1 specific cDNA fragment and autoradiography, an identical restriction pattern was observed for the seven control samples (Fig. 2) (data not shown). Likewise, an identical restriction pattern was seen among 20 of 21 leukemic samples tested (Fig. 2) (data not shown). A novel restriction pattern was detected upon analysis of one patient with a balanced translocation involving chromosomes 11q23 and 4q21. As shown in Fig. 2, novel 
Table 1 Clinical and cytogenetic characteristics of patients with 11q23 aberrations

\begin{tabular}{|c|c|c|}
\hline Patient/age (yr)/sex & Diagnosis & Karyotype \\
\hline $1 / 2 / \mathrm{M}$ & ALL/null cell & $46, X Y, t(4 ; 11)(q 21 ; q 23)$ \\
\hline $2 / 1 / \mathrm{M}$ & ALL/pre-B cell & $46, X Y, \operatorname{del}(11)(q 12-q$ ter $)$ \\
\hline $3 / 0.09 / F$ & ALL/null cell & $46, \mathrm{XX}, \mathrm{t}(4 ; 11)(\mathrm{q} 21 ; \mathrm{q} 23)$ \\
\hline $4 / 0.22 / \mathrm{M}$ & ALL/null cell & $46, X Y, \operatorname{ins}(5 ; 11)(q 31 ; q 23 q 13)$ \\
\hline $5 / 8 / F$ & ALL/pre-B cell & $46, \mathrm{XX}, \mathrm{t}(4 ; 11)(\mathrm{q} 21 ; \mathrm{q} 23)$ \\
\hline $6 / 0.29 / F$ & ALL/null cell & $46, \mathrm{XX}, \mathrm{t}(4 ; 11)(\mathrm{q} 21 ; \mathrm{q} 23)$ \\
\hline $7 / 14 / \mathrm{M}$ & ALL/null cell & $\begin{array}{l}82, \mathrm{XY},-2,-3,-4, \mathrm{t}(4 ; 11)(\mathrm{q} 21 ; \mathrm{q} 23) \times 2,-5,-7,-9,-9,-13,-14 \\
\quad-17,+21,-22\end{array}$ \\
\hline $8 / 4 / F$ & ALL/T-cell & $46, X X, ? i(9 q), \operatorname{del}(11)(q 23)$ \\
\hline $9 / 0.84 / F$ & ALL/null cell & $46, \mathrm{XX}, \mathrm{t}(4 ; 11)(\mathrm{q} 21 ; \mathrm{q} 23)$ \\
\hline $10 / 10 / \mathrm{F}$ & ALL/null cell & $46, X X, t(4 ; 11)(q 21 ; q 23)$ \\
\hline $11 / 5 / \mathrm{M}$ & ALL/T-cell & $45, X,-Y, \operatorname{del}(6)(q 13 q 21), \operatorname{del}(11)(q 14)$ \\
\hline $12 / 0.14 / \mathrm{M}$ & ALL/null cell & $46, X Y, t(11 ; 19)(q 23 ; p 13.3)$ \\
\hline $13 / 14 / \mathrm{M}$ & ALL/null cell & $46, \mathrm{XY}, \mathrm{t}(4 ; 11)(\mathrm{q} 21 ; \mathrm{q} 23), \mathrm{i}(7)(\mathrm{q} 10)$ \\
\hline $14 / 10 / F$ & ALL/null cell & $47, X X,+X, t(11 ; 19)(q 23 ; p 13)$ \\
\hline $15 / 4 / F$ & AML/M5a & $t(9 ; 11)(p 22 ; q 23)^{a}$ \\
\hline $16 / 65 / F$ & AML/M5a & $t(9 ; 11)(p 22 ; q 23)^{a}$ \\
\hline $17 / 7 / \mathrm{M}$ & $A_{L L}{ }^{b}$ & $t(4 ; 11)(q 21 ; q 23)^{a}$ \\
\hline $18 / 12 / \mathrm{M}$ & ALL $^{\mathbf{b}}$ & $\mathrm{t}(4 ; 11)(\mathrm{q} 21 ; \mathrm{q} 23)^{\mathrm{a}}$ \\
\hline $19 / 4 / \mathrm{M}$ & $A_{L L}^{b}$ & $\operatorname{del}(11)\left(\mathrm{q}_{23}\right)^{\mathrm{a}}$ \\
\hline $20 / 1 / M$ & $A_{L L}^{b}$ & $t(4 ; 11)(q 21 ; q 23)^{a}$ \\
\hline $21 / 22 / F$ & ALL $^{b}$ & $t(11 ; 14)(q 23 ; ?)^{a}$ \\
\hline
\end{tabular}

Abbreviations: ALL, acute lymphoblastic leukemia; AML, acute myelogenous leukemia.

${ }^{a}$ Complete karyotype not available.

${ }^{b}$ More detailed phenotype not available.

Figure 1 Structure of the ETS1 cDNA: 5' untranslated region (shaded box), ETS1 open reading frame (open box), and $3^{\prime}$ untranslated region (crosshatched box). The probe consisted of the 442-bp fragment at the $5^{\prime}$ region of the ETS1 cDNA ( $5^{\prime}$ ETS1 cDNA) and included 58 bp of $5^{\prime}$ untranslated region and 384 bp of ETS1 coding sequence.

\section{ETS-1 cDNA}

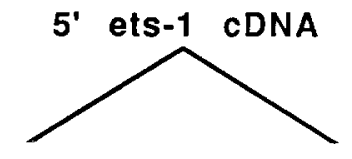

Xba I

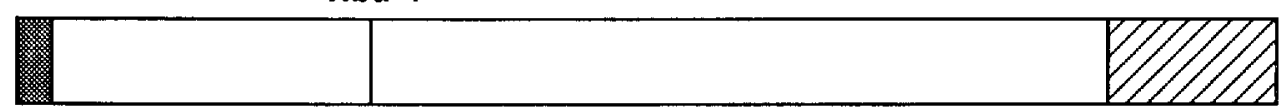

bp $\quad 158$

13821900

\section{5' Untranslated Region}

3' Untranslated Region

Open Reading Frame 

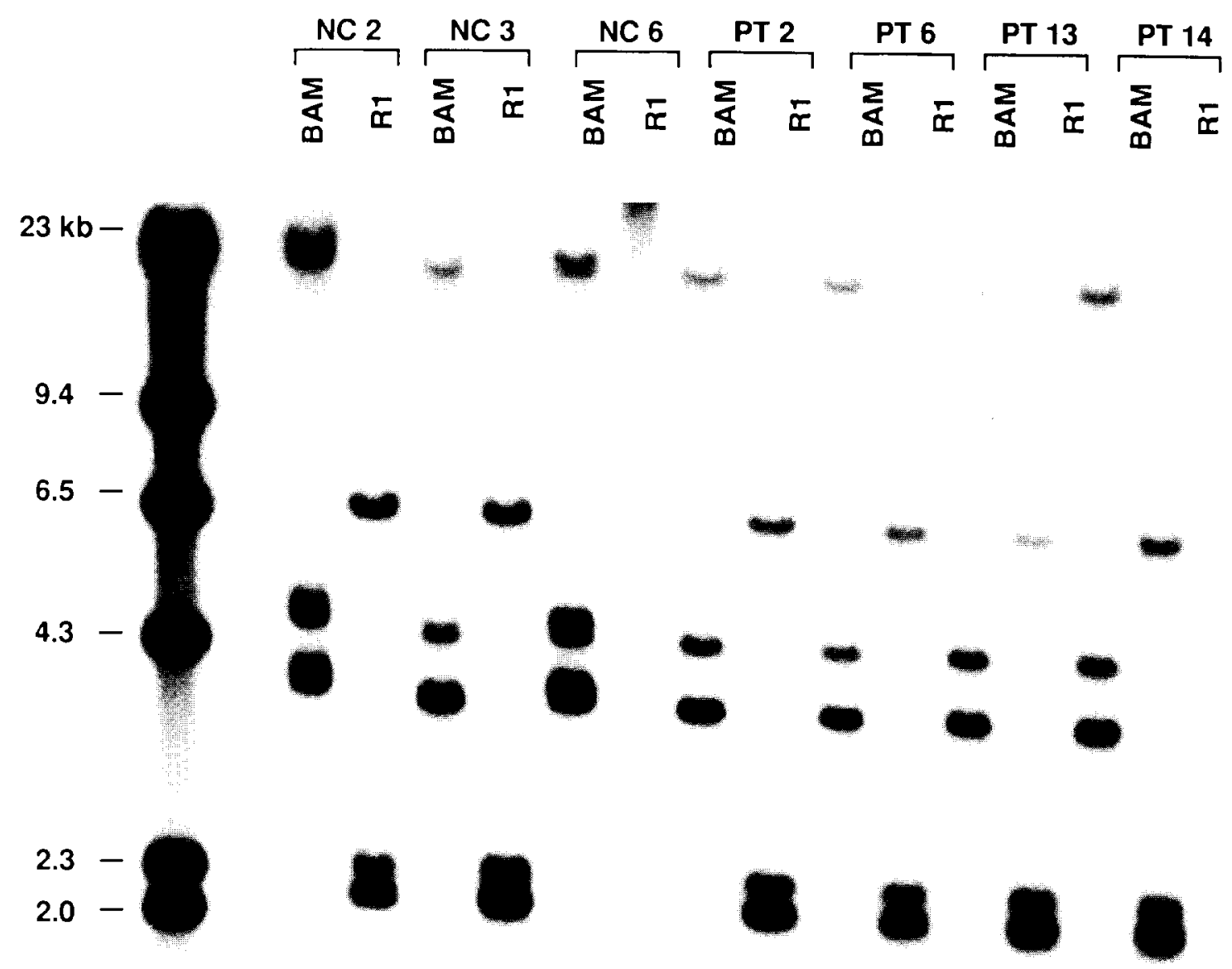

Figure 2 Analysis of the 5' ETS1 exon restriction pattern in patients with 11q23 translocations. Southern blot analysis of $5 \mu \mathrm{g}$ DNA from white blood cells of three normal control (NC) subjects and bone marrow of four patients with acute leukemia (patients 2, 6, 13, and 14) digested with BamHI (Bam) and EcoRI (RI) (lanes 2-14) and probed with the $5^{\prime}$ ETS1 cDNA fragment. Lane 1 contains ${ }^{32} \mathrm{P}$-labeled $\lambda$ DNA digested with HindIII. Of interest are the novel bands (16.5 and $4.7 \mathrm{~kb}$, respectively) detected in the BamHI and EcoRI digests of patient 13.

16.5 and $4.7 \mathrm{~kb}$ bands were noted in the BamHI and EcoRI digests respectively.

To define the potential translocation detected in this patient further, we constructed a genomic map of ETS1 and, from this, designed additional genomic DNA probes. The 5' ETS1 cDNA probe was used to screen a genomic library prepared from human peripheral blood lymphocytes. Positively hybridizing phage clones were isolated and mapped with several restriction endonucleases. Clone $\lambda 1613$ yielded a 6.5-kb EcoRI fragment that corresponded to the 6.5-kb band observed on Southern blots probed with the ETS1 5 ' fragment. This $6.5 \cdot \mathrm{kb}$ fragment was subcloned (ETS 1.3) and sequenced. It contained exon 1, as determined by homology to human ETS1 cDNA sequence, as well as the promoter region of ETS1 (S. Kim and C. Thompson, manuscript in preparation). Clone $\lambda 1609$ yielded two BamHI fragments measuring 4 and $5 \mathrm{~kb}$, respectively, and corresponding in length to two of the BamHI restriction fragment bands observed on Southern blots probed with the 5' ETS1 cDNA fragment. The two BamHI fragments were subcloned and partially sequenced. The 5-kb clone (ETS 1.1) contained the $109 \mathrm{bp}$ from the $5^{\prime}$ end of exon 2, and the 4-kb (ETS 1.2) clone contained the remaining $9 \mathrm{bp}$ of exon 2 as well as all of exon 3 (Fig. 3). To determine which fragment had acquired an altered migration pattern in the DNA from patient (PT) 13, we used the ETS 1.3 genomic clone containing the ETS1 promoter/enhancer region, first exon, and $5^{\prime}$ end of the first intron to isolate two ETS1-specific genomic DNA probes that flanked the first exon. The first probe ( $5^{\prime}$ ETS 1.3) contained the 850-bp EcoRI-HindIII fragment from the $5^{\prime}$ end of ETS 1.3. The second probe ( $3^{\prime}$ ETS 1.3) contained the 500-bp XbaI-EcoRI fragment from the $3^{\prime}$ end of ETS 1.3 (Fig. 3).

Southern blots containing restriction enzyme-digested DNA from PT 13 leukemia cells were consecutively hybridized with the $5^{\prime}$ and $3^{\prime}$ ETS 1.3 probes. In BamHI-restricted DNA, the 3' ETS 1.3 probe detected both the germline $22 \mathrm{~kb}$ fragment and the novel $16.5 \mathrm{~kb}$ fragment detected with the original 5' ETS1 cDNA probe (Fig. 4), whereas the 5' ETS 1.3 fragment detected both the germline 22-kb fragment and a novel band of $5.6 \mathrm{~kb}$ (Fig. 5). In EcoRI-restricted DNA, the 


\section{$1 \mathrm{~kb}$}

$5^{\prime}$ ets $1.3 \quad 3^{\prime}$ ets 1.3

ETS1.3
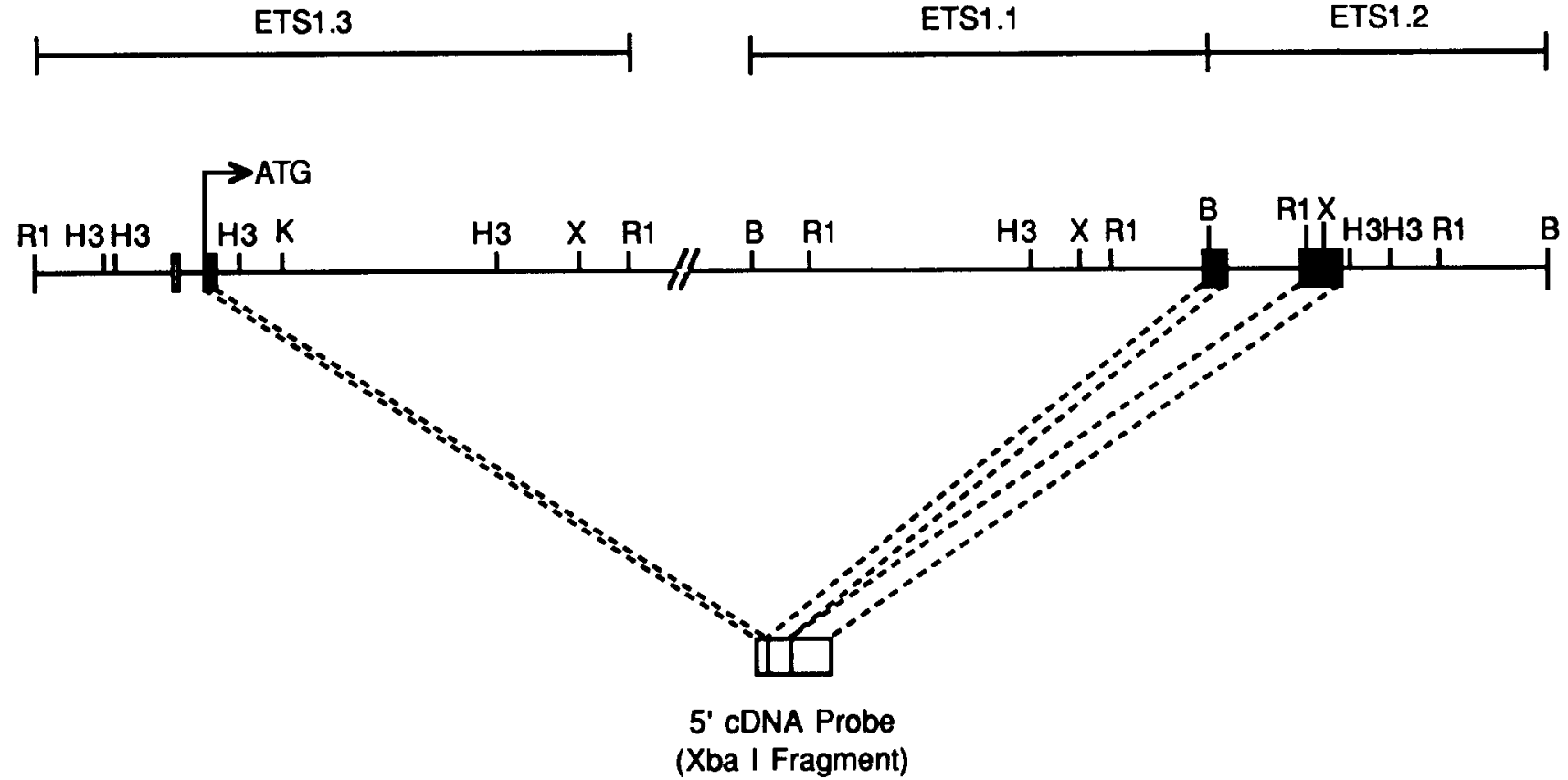

Figure 3 Genomic organization of $5^{\prime}$ end of ETS1. Shown are restriction maps of the genomic ETS1 clones used in these analyses as determined by restriction and partial sequence analysis. Location of exons 1-3 (bars), promoter region (box). Also shown in a schematic of the 5' ETS1 cDNA probe. The two genomic probes, $5^{\prime}$ and $3^{\prime}$ ETS 1.3, are diagrammed (top).

3' ETS 1.3 probe detected the germline 6.5-kb fragment and novel 4.7-kb fragment detected with the original 5' ETS1 cDNA probe, whereas the 5' ETS 1.3 fragment detected both the germline 6.5-kb fragment and a $1.8-\mathrm{kb}$ fragment. As shown in Fig. 5, the novel BamHI and EcoRI sites detected in this single patient were localized to the same site in the genomic map of ETS1 and, in both cases, the size of the novel bands detected by probes $5^{\prime}$ and $3^{\prime}$ of the breakpoint equaled the size of the parental fragment detected in control DNA by both probes. Likewise, data obtained using two additional restriction enzymes localized a DNA break to this same site (SacI and KpnI, data not shown). Thus, all four enzymes confirmed we were detecting a DNA break rather than a translocation. To determine whether the break was an isolated artifact of DNA preparation, we obtained a second sample of leukemic cells from this patient and reanalyzed it by Southern blot. The results were identical to those detected initially, implying that the DNA break could be reproducibly observed in serial leukemic samples.

We then performed DNasel-hypersensitive site analysis of the ETS1 promoter region, and noted that a major site of nuclease sensitivity mapped to the position of the breakpoint detected in the DNA isolated from the leukemic cells of patient 13 (Fig. 6), suggesting that the DNA break occurred artifactually in preparation of DNA from the frozen leukemic cells and demonstrating that rearrangements in or around the ETS1 promoter are not involved in 11q23 translocations. In one patient, however, we detected a DNA break which we mapped to the major DNaseI-hypersensitive site present in the ETS1 promoter.

\section{DISCUSSION}

The association between chromosome aberrations and protooncogenes have yielded important insights into the etiology of several human hematopoietic malignancies, including B-cell neoplasms and chronic myelogenous leukemia. Because the protooncogene ETS1 has been localized near the leukemia-specific breakpoint 11q23, that ETS1 was hypothesized to play a role in the leukemic process. Indeed, several 


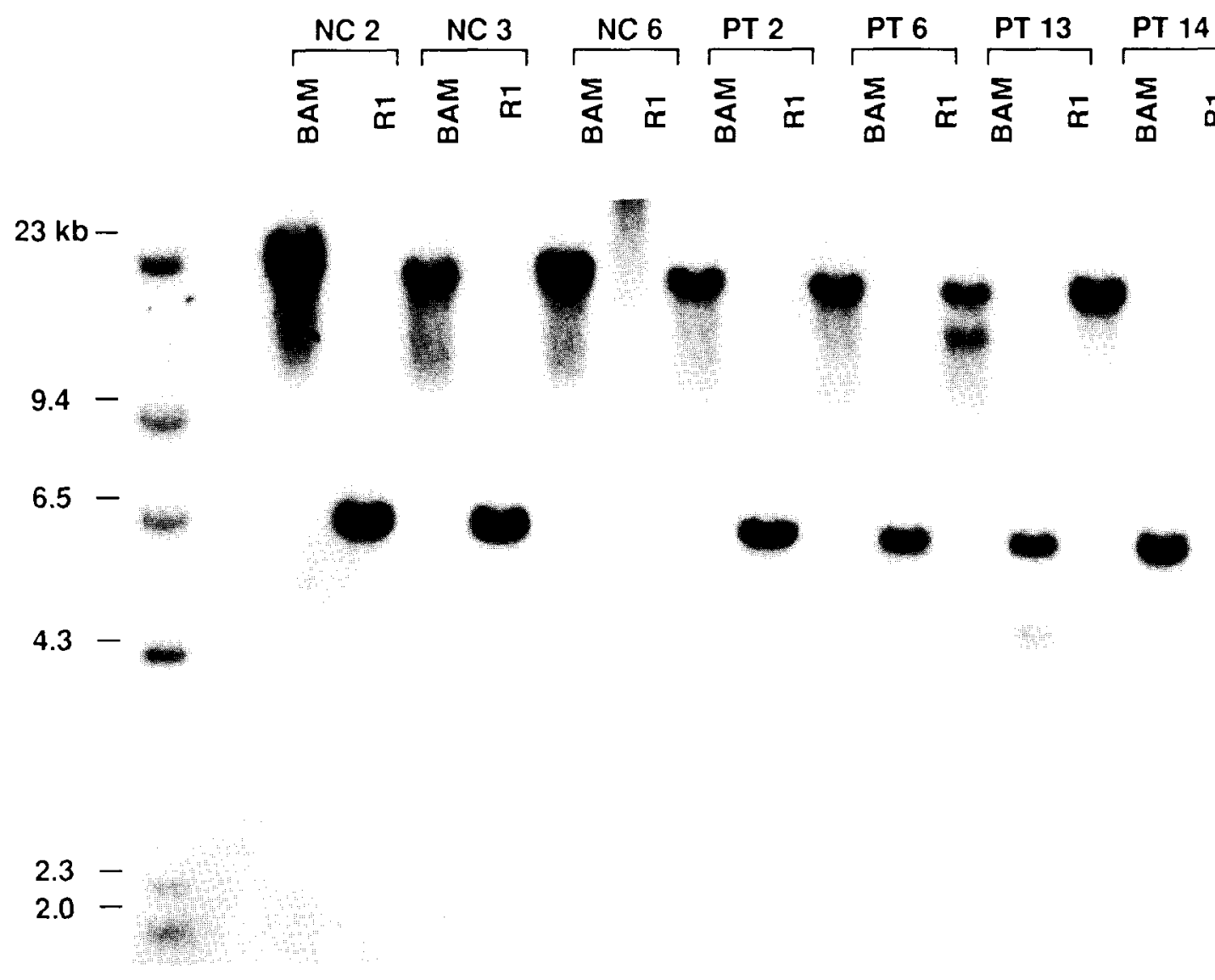

Figure 4 The aberrant restriction fragment observed in DNA from patient 13 contains the regions encoding the first exon. Southern blot shown in Fig. 2 was reprobed with the 3' ETS 1.3 genomic fragment. The same novel 16.5and 4.7-kb bands were detected by the 5' ETS1 cDNA probe.

cases of altered ETS1 restriction enzyme fragments were reported in cases of 11q23 translocation [12,13]. As part of our analysis of ETS1 gene expression, we had an opportunity to examine the ETS1 promoter region for rearrangement in 18 patients with 11q23 translocations. None of these patients had any evidence of translocation associated with the ETS1 gene. Therefore, our data are consistent with recently published reports that localize the $11 \mathrm{q} 23$ breakpoint at least several hundred kilobases centromeric of the ETS1 gene [18, 19].

In the course of our study, however, using multiple restriction enzymes, we identified a patient whose leukemic cell DNA consistently showed an altered ETS1 restriction enzyme fragment. These observations resulted from a breakpoint that mapped in the promoter region of ETS1. Such a DNA break must be artifactual because a chromosome with a double-strand break will undergo loss of the centromeredistal fragment during a subsequent cell division. DNaseIhypersensitive site analysis showed that the break mapped to the major nuclease-sensitive site in the promoter region of ETS1. Therefore, apparent alteration in the size of the restriction enzyme fragment alone is not sufficient justification to conclude that a chromosome translocation has occurred in the vicinity of a probe. Even if nonleukemic tissue from the patient fails to show a similar fragment, an endoge-

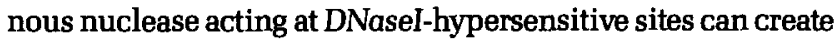
artifactual alterations in restriction fragment lengths in tumor samples. In this light, this work provides an important cautionary tale for workers investigating potential sites of chromosome translocation. Previous data reporting breakpoints involving ETS1 may have resulted from DNA breaks at nuclease-hypersensitive sites.

Supported in part by Grants No. CA-21765 (CORE), CA-30969, and CA-31566 from the National Cancer Institute and by the American Lebanese Syrian Associate Charities (ALSAC). The authors thank W. Kent Williams for help in obtaining patient material and Jeanelle Pickett for assistance in manuscript preparation.

\section{REFERENCES}

1. Watson DK, McWilliams-Smith MJ, Nunn MF, Duesberg PH, O'Brien SJ, Papas TS (1985): The ets sequence from the transforming gene of avian erythroblastosis virus, E26, has unique domains on human chromosomes 11 and 21: Both are transcriptionally active. Proc Natl Acad Sci USA 82:7294-7298.

2. Moscovici C, Samaut J, Gazzolo L, Moscovici MG (1981): My- 
A

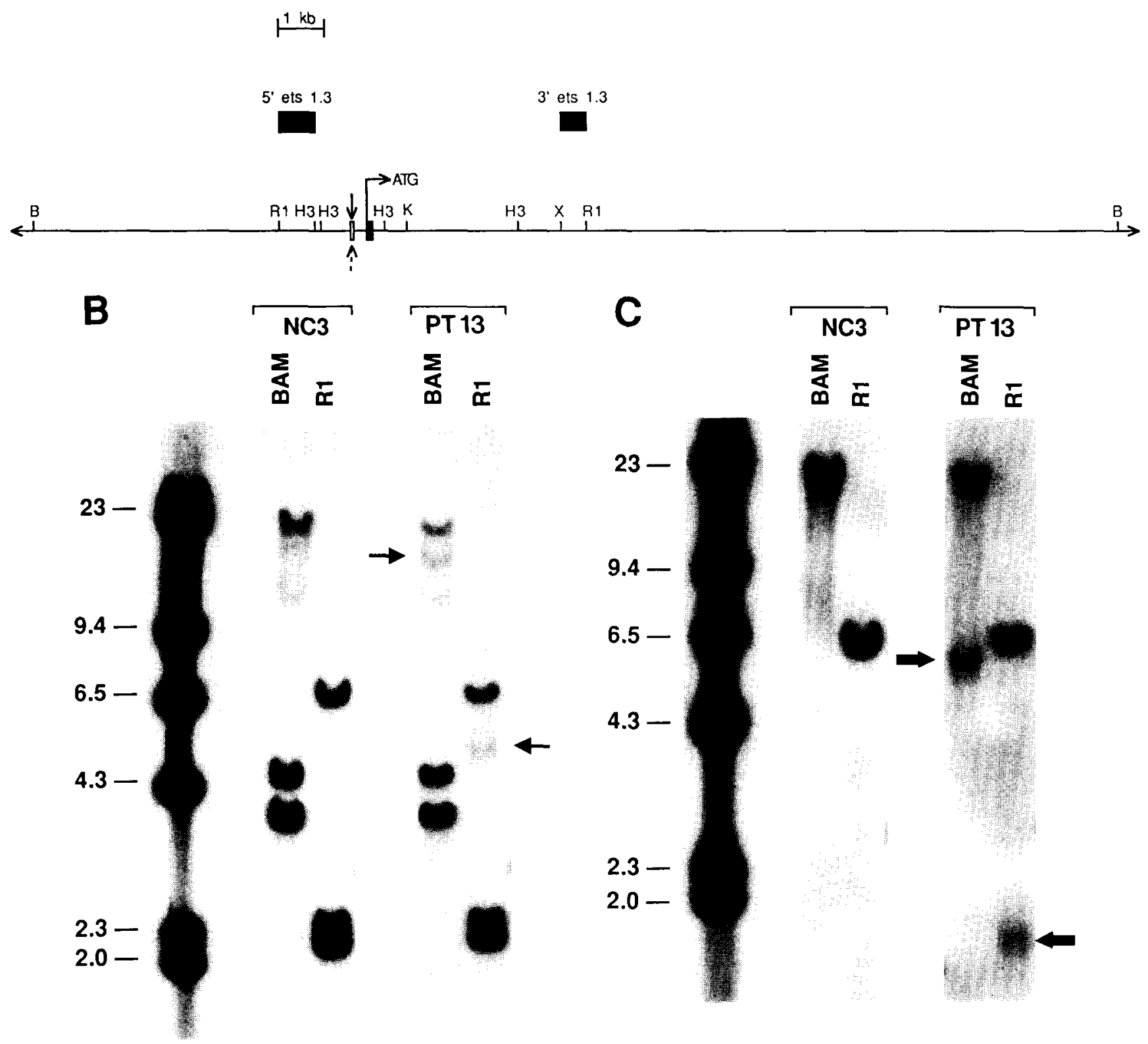

Figure 5 Genomic map of the ETS1 promoter region in relation to patient PT 13 (5A). Southern blot of $5 \mu \mathrm{g}$ of genomic DNA from NC3 and patient 13 digested with BamHI and EcoRI and probed consecutively with the ETS1 cDNA fragment containing the first exon described in the legend to Fig. 1 (B) and the 5' ETS 1.3 genomic fragment described in the legend to Fig. 3 (C). The arrows in B highlight the novel BamHI and EcoRI bands measuring 16.5 and $4.7 \mathrm{~kb}$, respectively (also shown in Fig. 2). Likewise, the arrows in C highlight the novel BamHI and EcoRI bands measuring 5.6 and $1.8 \mathrm{~kb}$, respectively. Novel BamHI and EcoRI sites detected in patient 13 digests (solid and broken arrows, respectively, 5A).

eloid and erythroid neoplastic responses to avian defective leukemia viruses in chickens and in quail. Virology 113:765-768.

3. Radke K, Beug H, Kornfeld S, Graf T (1982): Transformation of both erythroid and myeloid cells by E26, an avian leukemia virus that contains the myb gene. Cell 31:643-653.

4. Bhat NK, Fisher RJ, Fujiwara S, Ascione R, Papas TS (1987): Temporal and tissue-specific expression of mouse ets genes. Proc Natl Acad Sci USA 84:3161-3165.
5. Bhat NK, Komschlies KL, Fujiwara S, Fisher RJ, Mathieson BJ, Gregorio TA, Young HA, Kasik JW, Ozato K, Papas, TS (1989): Expression of ets genes in mouse thymocyte subsets and $T$ cells. J Immunol 142:672-678.

6. Pognonec P, Boulukos KE, Ghysdael I (1989): The c-ets-1 protein is chromatin associated and binds to DNA in vitro. Oncogene $4: 691-678$.

7. Ho I-C, Bhat NK, Gottschalk LR, Lindsten T, Thompson CB, 


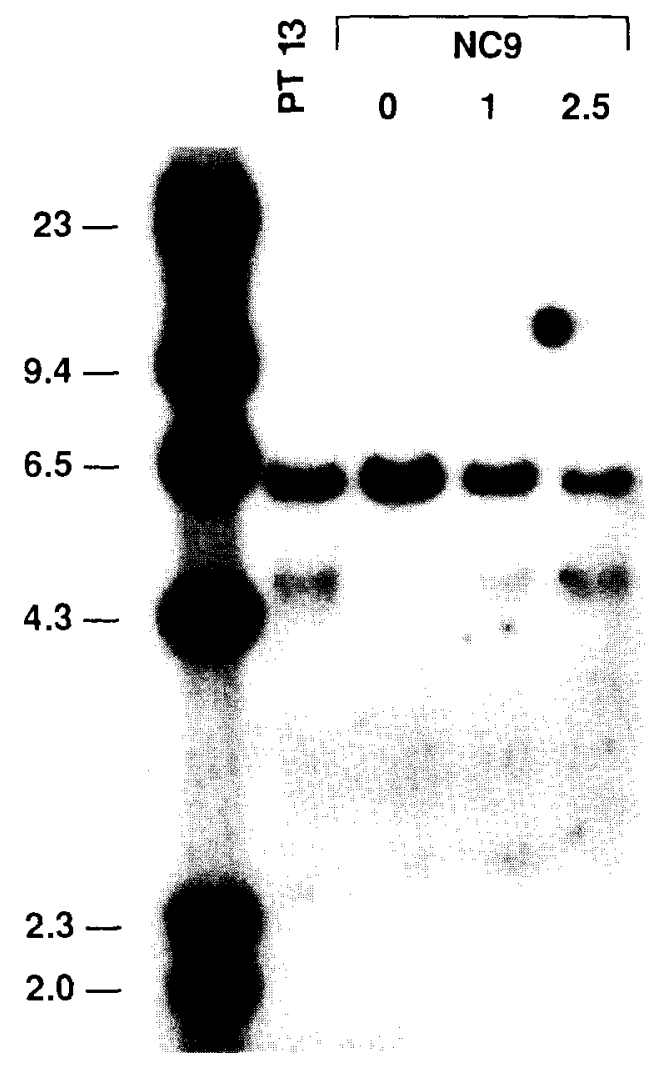

Figure 6 The DNA breakpoint observed in patient 13 occurs at the major DNAseI-hypersensitive site in the ETS1 promoter/enhancer. Southern blot of $5 \mu \mathrm{g}$ genomic DNA from normal human peripheral blood $T$ cells treated with varying concentrations of DNAsel $(0,1$, and $2.5 \mu \mathrm{g} / \mathrm{ml}$ ) and DNA from patient 13, digested with EcoRI, and probed with the $3^{\prime}$ ETS 1.3 probe. The DNA break in the promoter region of ETS1 in the DNA from leukemic cells from patient 13 maps to the major DNAseI-hypersensitive site in the ETS1 promoter.

Papas TS, Leiden JM (1990): Sequence-specific binding of human ETS1 to the T cell receptor $\alpha$ gene enhancer. Science 250:814-817.

8. Gunther CV, Nye JA, Bryner RS, Graves BJ (1990): Sequencespecific DNA binding of the proto-oncoprotein ets-1 defines a transcriptional activator sequence within the long terminal repeat of the Moloney murine sarcoma virus. Genes Dev 4:667-679.

9. Bhat NK, Thompson CB, Lindsten T, June CH, Fujiwara S, Koizumi S, Fisher RJ, Papas TS (1990): Reciprocal expression of ETS1 and ETS2 genes during T cell activation: A novel regulatory role for the proto-oncogene ETS1. Proc Natl Acad Sci USA 87:3723-3727.

10. Fisher CL, Ghysdsel J, Cambier JC (1991): Ligation of membrane Ig leads to calcium-mediated phosphorylation of the protooncogene product, ETS1. J Immunol 146:1743-1749.

11. de Taisne C, Gegonne A, Stehelin D (1984): Chromosomal localization of the human protooncogene c-ets. Nature 310:581-583.

12. Goyns MH, Hann LM, Stewart J, Gegonne A, Binie GD (1987): The c-ets-1 proto-oncogene is rearranged in some cases of acute lymphoblastic leukaemia. Br J Cancer 56:611-613.

13. Savage PD, Hanson CA, Kersey JH (1987): Identification of a restriction fragment length polymorphism involving the oncogene ETS1 on chromosome 11q23. Blood 70:327-329.

14. Kennedy MA, Morris CM, Fitzgerald PH (1989): The oncogene ETS1 is distant from the chromosome 11 breakpoint in leukaemic cells with the $t(11 ; 19)(q 23 ; p 13)$. Leuk Res 13:459-463.

15. Ohyashiki K, Ohyashiki JH, Kazurshi N, Ryan DH, Kinniburgh AJ, Sandberg AA (1988): Hu-ets-1 gene in congenital leukemia with $t(11 ; 19)$ ( $q 23 ; p 13)$. Cancer Genet Cytogenet 30:233-238.

16. Sacchi N, Watson DK, Guerts van Kessel HM, Hagemeijer A, Kersey J, Drabkin HD, Patterson D, Papas TS (1986): Hu-ets-1 and Hu-ets-2 genes are transposed in acute leukemias with $(4 ; 11)$ and $(8 ; 21)$ translocations. Science 231:379-382.

17. Akao Y, Tsujimoto Y, Finan J, Nowell PC, Croce CM (1990): Molecular characterization of a $t(11 ; 14)(q 23 ; q 32)$ chromosome translocation in a B-cell lymphoma. Cancer Res 50:4856-4859.

18. Cimino G, Moir DT, Canaani O, Williams K, Crist WM, Katzav S, Cannizzaro L, Lange B, Nowell PC, Croce CM, Canaani E (1991): Cloning of $A L L-1$, the locus involved in leukemias with the $t(4 ; 11)(q 21 ; q 23), t(9 ; 11)(p 22 ; q 23)$, and $t(11 ; 19)(q 23 ; p 13)$ chromosome translocations. Cancer Res 51:6712-6714.

19. Ziemin-van der Poel S, McCabe NR, Gill HJ, Espinosa R, Patel Y, Harden A, Rubinelli P, Smith SD, LeBeau MM, Rowley JD, Diaz MO (1991): Identification of a gene, MLL, that spans the breakpoint in 11q23 translocations associated with human leukemias. Proc Natl Acad Sci USA 88:10735-10739.

20. Thompson CB, Neiman PE (1987): Somatic diversification of the chicken immunoglobulin light-chain gene is limited to the rearranged variable gene segment. Cell 48:369-378. 